\title{
Effect of Magnetic Treatment for Irrigation Ground Water on Soil Salinity, Nutrients, Water Productivity and Yield Fruit Trees at Sandy Soil
}

\author{
N.E. Fanous, Amira A. Mohamed and Kh. A. Shaban \\ Soil, Water and Environment Research, Agric. Res. Center, Giza, Egypt
}

T

HIS APPLIED experiment was conducted at private farm (160 feddans), sustained of soil and water salinity, at km80 of cairo-alexandria desert road (the green wealth farms). four electromagnetic devise (6 inch) set up on the main sources of ground irrigation. one well for each agriculture sector apricot, peach, flame-seedless grape and thompson seedless grape sectors. these sectors has been irrigated by magnetic treated water (mtw), beginning of december2013, through a drip system.

The results indicated that $\mathrm{mtw}$ has led to non-significant decrease of water salinity (only from 2.183.31- to 2.14- 3.12 dsm-1), ph (from 8.2- 8.3 to 8.258.15-), sar (from 6.47.7- to 5.66.0 ) and hypothetical nacl (from $57.37-60.53 \%$ to $53.31-58.15 \%$ )

Concerning the effect of mtw on soil chemical properties, the data showed that soil salinity was decreased after using mtw compared with the normal water. soil salinity was decreased from 4.88- 6.15 dsm-1 to 2.734.15-dsm-1 and 1.452.83- dsm-1 after one month and eight ones of the magnetic treatment, respectively. besides, ph values were reduced from 8.28.3- to 7.98.05 before and after magnetic treatment respectively. as well as the hypothetical nacl and $\mathrm{mgcl} 2$ were diminished from $21.5 \mathrm{meq} / 1$ and $8.0 \mathrm{meq} / 1$ to 6.3 and $3.0 \mathrm{meq} / 1$ through eight months from the treatment. it is worth mentioning that the magnetic irrigation had good effects on the availability of npk and micronutrients (fe, $\mathrm{zn}, \mathrm{cu}$ and $\mathrm{mn}$ ) all during fertilization season, entail the observed increasing on the yield of fruits. thus, the results indicated that the main beneficial of using mtw were in improving yield for apricot, peach, flame-seedless grape and thompson seedless grape to 40.0, 29.028 .0 and 19.0\% respectively. also, raising the efficiency of water productivity to $40.2,29.2,28.0$ and $19.3 . \%$, respectively.

Keywords: Magnetic water treatment, Electromagnetic device, Sandy soil, Water and soil salinity, Crop and water productivity.

\section{Introduction}

Future availability of pleasing water for agriculture in Egyptian deserts is problematic, as a result of the increase concentration in salinity of the ground irrigation water at several regions. Now, numerous farms in the newly reclaimed soils were irrigated with saline water either from ground wells or treated sewage water, therefore the importance of physical treatment of saline water using magnetic devices become feasible. Magnetic treated water (MTW) is considered as environmentally friendly technique (Nimmi and Medhu, 2009). MTW is produced when water passes through the magnetic field of magnetic permanent device or electromagnetic one, installed on feed pipeline, where all water and salt molecules have internal vibration (Babu, 2010). MTW removes the excess of the soluble salts; reduces $\mathrm{pH}$ values, due to MTW have solving for soil salts, and leaches the salts away from roots zone (Hilal et al., 2012). Selim 2008 stated that MTW has induced changes in the solubility of $\mathrm{CaCO} 3$ and gypsum. He also indicated that MTW has induced changes in the mobility of nutrient elements in root zone which differces from one element to another according to the element magnetic susceptibility. Using MTW is improved the crop yield and water productivity and save water supply especially with the future water scarcity as mentioned Duarte Diaz etal. (1997) and Hilal et al. (2012) 
The main target of this work is to study the effect of the magnetic treated water (MTW) on irrigation with saline water and its efficiency on salt removal from saline sandy soil, and on the availability of main nutrients, as well as the yield of fruits trees and water productivity.

\section{Materials and Methods}

Four field experiments were conducted at a private farm (160 feddans), sustained of soil and water salinity, at Km80 of Cairo-Alexandria desert road (the Green Wealth farms).A four electromagnetic devise (6 inch) was set up on the main sources of ground irrigation. One well for each agriculture sector, apricot, peach, Flame-seedless grape and Thompson seedless grape sectors. These sectors have been irrigated by magnetic treated water (MTW), beginning of December 2013, through a drip irrigation system. One area was selected and bordered at every cultivated sector. Each experimental area includes three dripper's lines (Fig.1).

The magnetic irrigation water was obtained by passing irrigation water through electro-magnetic device installed on every feed water well (EWN Sharaf-3 device, from ITEN Company at Egypt; 220V. 50 CIS or 12 V.D.C. and power consumption $2.4 \mathrm{~W} /$ unit). Every device is six inch in diameters which has water discharge about 120 $\mathrm{m} 3 / \mathrm{hr}$. All fertilizers were applied according to the recommendation of the Ministry of Agriculture, Egypt. The fertigation technique was used into a drip irrigation system for NPK-nutrients. Meanwhile, $\mathrm{Fe}, \mathrm{Zn}, \mathrm{Cu}$ and $\mathrm{Mn}$-nutrients are fertilized using spray method. All trees received farmyard manure at rate of $20 \mathrm{~m} 3 /$ fed.

The cultivation distance between trees of apricot, peach, Flame-seedless grape and Thompson seedless grape are $5 \times 5,5 \times 4,3 \times 1.75$ and $3 \times 1.75 \mathrm{~m}$, respectively. The drip laterals with drippers were placed at the two sides of trees. The irrigation took place according to the evapotranspiration in this region, namely $2 \mathrm{~mm}$ at December, January and February; $3 \mathrm{~mm}$ at March and November; $5 \mathrm{~mm}$ at April, May, September and October, and $7 \mathrm{~mm}$ at June, July and August. The total water quantity is $3524 \mathrm{~m} 3 /$ fed. yearly. Thus, the water use per tree yearly for apricot, peach, Flame-seedless grape and Thompson seedless grape is $20.95,16.78,4.41$ and $4.41 \mathrm{~m} 3 /$ tree, respectively.

Water irrigation samples were taken two-times, the first before setting up the electromagnetic devices (control) and the second six months after fastening the device (MTW). The obtained water samples were submitted to chemical analysis. EC, soluble cations and anions and $\mathrm{pH}$. As well as soluble Fe, $\mathrm{Zn}, \mathrm{Cu}$ and $\mathrm{Mn}$ (Table 3 ) were estimated by atomic absorption spectrophotometer .

Soil samples were collected from four sites

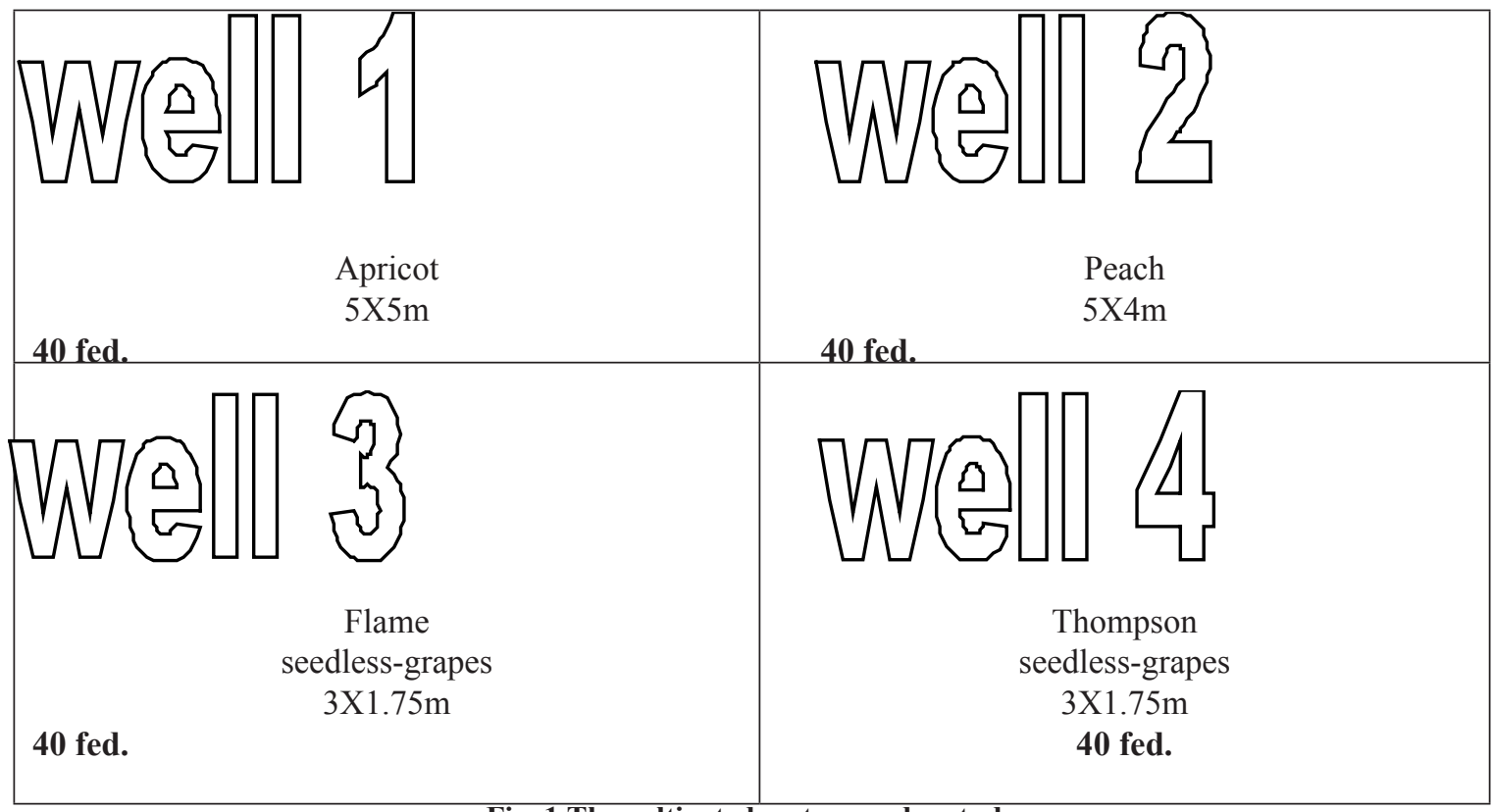

Fig. 1.The cultivated sectors under study 
(Replicated) each of apricot, peach, Flame-seedless grape and Thompson seedless grape sectors. The soil samples (at $40 \mathrm{~cm}$ depth) were taken threetimes; the first one before installing magnetic devices (control). The second and third ones one month after magnetic treatment (January, 2014) and eight months (July, 2014). The main characteristics of soil sites were determined according to Bashour and Sayegh (2007) (Tables 1 and 2).

The Hypothetical salts compositions were calculated for water and soil samples (using Solen System and Planer Graphic according to Arab Mining and Petroleum Ass.(1970).

Mean fresh weight of fruit yields ( $\mathrm{Kg} /$ tree) for each of eight Apricots, eight peach, and fifteen Flame-seedless grapes and fifteen Thompson seedless-grape trees were recorded.

Water productivity was computed as mean fruit yield $(\mathrm{kg})$ per water use (m3) according to Larcher (1995).

\section{Results and Discussion}

Soil and water properties under study before the magnetic irrigation water

Soil properties

Data in Table 1 show the percentage of particle size distribution of the soil under study at the Green Wealth Farm, km 80 Cairo -Alexandria desert road. The soil is characterized by a sand texture (86.9 - 89.9\% sand, 5.3-6.3 silt and 4.8$6.8 \%$ clay), with low content of organic matter $(0.5-0.7 \%)$ and $\mathrm{CaCO} 3$ content is ranged between $7.1-8.2 \%$.

Chemical properties of irrigation water before magnetic treatment

The results of chemical analysis for ground water before magnetic treatment were given in Table 3. The electrical conductivity (EC) of the four wells under study is $2.18,2.55,2.81$ and $3.31 \mathrm{dSm}-1$ which lie at apricot, peach, and Flame seedless grape and Thompson seedless grape regions, respectively.

TABLE 1 . Mechanical analysis of soil samples at the different regions under study

\begin{tabular}{|c|c|c|c|c|c|c|}
\hline Location & $\begin{array}{c}\text { Particle size } \\
\text { distribution } \\
\% \\
\end{array}$ & & & $\begin{array}{c}\mathrm{CaCO}_{3} \\
\%\end{array}$ & $\begin{array}{c}\text { OM } \\
\%\end{array}$ & Texture \\
\hline & sand & silt & clay & & & \\
\hline Apricot region & 89.9 & 5.3 & 4.8 & 7.8 & 0.5 & sand \\
\hline Peach region & 88.7 & 5.4 & 5.9 & 7.3 & 0.6 & sand \\
\hline Flame seedless -grape region & 87.8 & 5.5 & 6.7 & 8.2 & 0.6 & sand \\
\hline $\begin{array}{l}\text { Thompson seedless- grape } \\
\text { region }\end{array}$ & 86.9 & 6.3 & 6.8 & 7.1 & 0.7 & sand \\
\hline
\end{tabular}

TABLE 2. Some soil chemical properties 1 month before magnetic

\begin{tabular}{|c|c|c|c|c|}
\hline Properties & $\begin{array}{l}\text { Apricot } \\
\text { region }\end{array}$ & $\begin{array}{l}\text { Peach } \\
\text { region }\end{array}$ & $\begin{array}{l}\text { Flame seedless } \\
\text {-grape region }\end{array}$ & $\begin{array}{l}\text { Thompson seedless } \\
\text {-grape region }\end{array}$ \\
\hline \multirow{2}{*}{$\begin{array}{c}\mathrm{SP} \\
* \mathrm{EC}\left(\mathrm{dSm}^{-1}\right) \\
\mathrm{pH}\end{array}$} & 19.5 & 10.0 & 21.0 & 22.0 \\
\hline & 8.3 & 8.3 & 8.2 & 8.2 \\
\hline \multicolumn{5}{|l|}{$\begin{array}{l}\text { Soluble cations } \\
\mathrm{meq} / 1\end{array}$} \\
\hline \multirow{3}{*}{$\begin{array}{c}\mathrm{Ca}^{+2} \\
\mathrm{Mg}^{+2} \\
\mathrm{Na}^{+} \\
\mathrm{K}^{+}\end{array}$} & 5.8 & 8.8 & 9.9 & 10.8 \\
\hline & 15.1 & 19.2 & 23.5 & 28.1 \\
\hline & 1.0 & 1.4 & 1.6 & 1.3 \\
\hline \multicolumn{5}{|c|}{ Soluble anions meq/1 } \\
\hline $\begin{array}{l}\mathrm{CO}_{3}^{-2} \\
\mathrm{HCO}_{3} \\
\mathrm{Cl}^{-} \\
\mathrm{SO}_{4}^{-2}\end{array}$ & ---- & -- & -- & -- \\
\hline
\end{tabular}

*the main value for $\mathrm{EC}: 5.27 \mathrm{dSm}^{-1}$ 
TABLE 3. Some chemical properties of the irrigation water before magnetic treatment

\begin{tabular}{|c|c|c|c|c|c|c|}
\hline \multirow[t]{2}{*}{ Properties } & \multicolumn{6}{|c|}{ Well Location } \\
\hline & well 1 & well 2 & \multicolumn{2}{|c|}{ well 3} & well 4 & $\begin{array}{l}\text { Mean } \\
\text { value }\end{array}$ \\
\hline \multirow{2}{*}{$\begin{array}{l}\text { EC }\left(\mathrm{dsm}^{-1}\right) \\
\text { TDS (ppm) }\end{array}$} & 2.18 & 2.55 & \multicolumn{2}{|l|}{2.81} & 3.31 & 2.71 \\
\hline & 1388 & 1632 & \multicolumn{2}{|l|}{1798} & 2118 & 1734 \\
\hline pH & 8.3 & 8.25 & \multicolumn{2}{|l|}{8.25} & 8.2 & 8.25 \\
\hline \multirow{2}{*}{\multicolumn{7}{|c|}{ Soluble cations meq/l }} \\
\hline & 7.0 & 8.3 & \multicolumn{2}{|l|}{8.8} & 9.9 & 8.5 \\
\hline \multirow{2}{*}{$\begin{array}{l}\mathbf{M g}^{+2} \\
\mathbf{N a}^{+}\end{array}$} & 1.4 & 2.0 & \multicolumn{2}{|l|}{2.7} & 3.2 & 2.3 \\
\hline & 13.8 & 14.4 & \multicolumn{2}{|l|}{16.6} & 19.6 & 16.1 \\
\hline$\underset{\text { Soluble anions meq/l }}{\mathrm{K}^{+}}$ & 0.4 & 0.4 & \multicolumn{2}{|l|}{0.5} & 0.5 & 0.5 \\
\hline \multirow{2}{*}{$\mathrm{CO}_{3}^{-2}$} & & & \multirow{2}{*}{\multicolumn{2}{|c|}{--}} & & \\
\hline & --- & -- & & & -- & \\
\hline \multirow{2}{*}{$\begin{array}{c}\mathrm{HCO}_{3} \\
\mathrm{Cl}^{-}\end{array}$} & 1.7 & 1.8 & \multicolumn{2}{|l|}{2.5} & 2.6 & 2.2 \\
\hline & 17.6 & 18.9 & \multicolumn{2}{|l|}{21.6} & 24.3 & 20.6 \\
\hline $\mathrm{SO}_{4}^{-2}$ & 3.3 & 4.4 & \multicolumn{2}{|l|}{4.5} & 6.3 & 4.6 \\
\hline SAR & 6.7 & 6.4 & \multicolumn{2}{|l|}{6.9} & 7.7 & 6.9 \\
\hline Class of water & C3-S2 & C4-S2 & $\mathrm{C} 4-\mathrm{S} 2$ & & C4-S2 & C4-S2 \\
\hline \multicolumn{7}{|l|}{$\begin{array}{l}\text { Available of } \\
\text { micronutrients (ppm) }\end{array}$} \\
\hline \multirow{2}{*}{$\begin{array}{l}\mathbf{F e} \\
\mathrm{Zn}\end{array}$} & 1.5 & \multicolumn{2}{|c|}{1.4} & 1.7 & 1.7 & 1.6 \\
\hline & 1.5 & \multicolumn{2}{|c|}{1.3} & 1.7 & 1.4 & 1.5 \\
\hline \multirow{2}{*}{$\begin{array}{l}\mathrm{Cu} \\
\mathrm{Mn}\end{array}$} & 0.2 & \multicolumn{2}{|c|}{0.2} & 0.2 & 0.2 & 0.2 \\
\hline & 0.1 & \multicolumn{2}{|c|}{0.1} & 0.2 & 0.2 & 0.2 \\
\hline
\end{tabular}

$\mathrm{C}_{3}=$ High salinity water $\quad \mathrm{C}_{4}=$ very high salinity water $\quad \mathrm{S}_{2}=$ medium sodium water.

$\mathrm{pH}$ values for the same above wells are 8.3 , $8.25,8.25 \& 8.2$, respectively. Water salinity of well No.1 (apricot sector) sets at category C3 - S2 namely high salinity with medium sodium adsorption ratio (SAR 6.7). The water of other wells $(2,3$ \& 4$)$ set at category C4-S2 namely, very high salinity with medium sodium adsorption ration (SAR 6.4 -7.7). UNDESCO System, 1954.

The mean content of micro-elements in the irrigation water before magnetic treatment is 1.6, 1.5, 0.2 and $0.2 \mathrm{ppm}$ for $\mathrm{Fe}, \mathrm{Zn}, \mathrm{Cu}$ and $\mathrm{Mn}$, respectively. These values are very low.

The salinity of irrigation water was about 1388 , 1632, 1798 and 2118 ppm at Nov.2013 for well 1,2, 3 and 4 respectively. Concerning, the hypothetical salts composition, the dominant salts in the normal water without magnetization as a mean values of the four wells are $58.8 \% \mathrm{NaCl}, 16.79 \% \mathrm{CaSO} 4$, $8.36 \% \mathrm{MgCl} 2,8.03 \% \mathrm{Ca}(\mathrm{HCO} 3) 2,6.20 \% \mathrm{CaCl} 2$ and $1.82 \% \mathrm{KCl}$.(Table 4 ).

Magnetic water treatment (MTW)

The changes in water soluble salts, $\mathrm{pH}$, micronutrients and salts composition at the irrigation water after one month of the magnetic treatment are shown in Tables $5 \& 6$. It noticed that the TDS value of ground water decreased from $1734 \mathrm{ppm}$ before the magnetic treatment to $1665 \mathrm{ppm}$ after magnetic due to decrease in the water content of chlorides salts, i.e. $\mathrm{NaCl}, \mathrm{KCL}, \mathrm{CaCl} 2$ and $\mathrm{MgCl}$, from $75.18 \%$ before the magnetic treatment to $72.63 \%$ after magnetic. The percentage of decrease of chloride was about $3.5 \%$. Hozien (2014) and Stephen (2013) mentioned that the magnetic field volatilizes chlorides as chlorine gas and that can reduce the salinity about $10 \%$.

In spite of the ability MTW to slightly decrease the salinity than in untreated water, however, the salinity categories of MTW still located at the same classes of untreated water (Table 5), i.e. C3-S2 for well No.1 and C4-S4 for wells No. 2,3 \&4. Also, there is not any evident for change in the content of microelements ( $\mathrm{Fe}, \mathrm{Zn}, \mathrm{Cu} \& \mathrm{Mn}$ ) before and after magnetic treatment. As well as $\mathrm{pH}$ values have a slight decrease from 8.2-8.3 to 8.15-8.25 before and after treatment, respectively. 
TABLE 4. The hypothetical composition of the irrigation water before magnetic treatment

\begin{tabular}{|c|c|c|c|c|c|c|c|c|}
\hline Location & $\begin{array}{l}\text { Magnetic } \\
\text { treatment }\end{array}$ & $\begin{array}{c}\text { TDS } \\
(\mathrm{ppm})\end{array}$ & $\begin{array}{c}\mathrm{Ca}\left(\mathrm{HCO}_{3}\right)_{2} \\
\%\end{array}$ & $\begin{array}{c}\mathrm{CaSO}_{4} \\
\%\end{array}$ & $\begin{array}{c}\mathrm{CaCl}_{2} \\
\%\end{array}$ & $\begin{array}{c}\mathrm{MgCl}_{2} \\
\%\end{array}$ & $\begin{array}{c}\mathrm{NaCl} \\
\%\end{array}$ & $\begin{array}{c}\mathrm{KCl} \\
\%\end{array}$ \\
\hline Well (1) & $\begin{array}{c}\text { Without } \\
\text { (Nov.2013) }\end{array}$ & 1388 & 7.47 & 14.90 & 7.13 & 6.6 & 60.33 & 1.75 \\
\hline Well (2) & $\begin{array}{c}\text { Without } \\
\text { (Nov.2013) }\end{array}$ & 1632 & 8.11 & 17.53 & 8.37 & 7.96 & 57.37 & 1.60 \\
\hline Well (3) & $\begin{array}{c}\text { Without } \\
\text { (Nov.2013) }\end{array}$ & 1798 & 8.74 & 15.73 & 6.30 & 9.44 & 58.04 & 1.75 \\
\hline Well (4) & $\begin{array}{c}\text { Without } \\
\text { (Nov.2013) }\end{array}$ & 2118 & 7.80 & 19.00 & 3.00 & 9.40 & 59.30 & 2.18 \\
\hline $\begin{array}{l}\text { Mean } \\
\text { values: }\end{array}$ & $\begin{array}{c}\text { Without } \\
\text { (Nov.2013) }\end{array}$ & 1734 & 8.03 & 16.79 & 6.20 & 8.36 & 58.80 & 1.82 \\
\hline
\end{tabular}

TABLE 5. Effect of magnetic water treatment on chemical properties of the irrigation ground water

\begin{tabular}{|c|c|c|c|c|c|c|c|c|}
\hline \multirow[t]{3}{*}{ Properties } & \multicolumn{8}{|c|}{ Well location } \\
\hline & \multicolumn{2}{|c|}{ well 1} & \multicolumn{2}{|c|}{ well 2} & \multicolumn{2}{|c|}{ well 3} & \multicolumn{2}{|c|}{ well 4} \\
\hline & Without & with & Without & with & Without & with & Without & With \\
\hline \multirow{2}{*}{$\begin{array}{c}\mathrm{EC}\left(\mathrm{dsm}^{-1}\right) \\
\mathrm{pH}\end{array}$} & 2.18 & 2.14 & 2.55 & 2.49 & 2.81 & 2.66 & 3.31 & 3.12 \\
\hline & 8.3 & 8.25 & 8.25 & 8.2 & 8.25 & 8.2 & 8.2 & 8.15 \\
\hline \multicolumn{9}{|l|}{ Soluble cations meq/l } \\
\hline \multirow{5}{*}{$\begin{array}{c}\mathrm{Ca}^{+2} \\
\mathrm{Mg}^{+2} \\
\mathrm{Na}^{+} \\
\mathrm{K}^{+} \\
\text {Soluble anions meq/1 }\end{array}$} & 7 & 8.0 & 8.3 & 9.8 & 8.8 & 10.1 & 9.9 & 11.7 \\
\hline & 1.4 & 1.3 & 2.0 & 1.4 & 2.7 & 1.6 & 3.2 & 2.2 \\
\hline & 13.8 & 13.2 & 14.4 & 13.3 & 16.6 & 14.6 & 19.6 & 16.7 \\
\hline & 0.4 & 0.2 & 0.4 & 0.4 & 0.5 & 0.4 & 0.5 & 0.5 \\
\hline & & & & & & & & \\
\hline \multirow{3}{*}{$\begin{array}{c}\mathrm{CO}_{3}^{-2} \\
\mathrm{HCO}_{3} \\
\mathrm{Cl}^{-}\end{array}$} & -- & -- & -- & -- & -- & -- & -- & -- \\
\hline & 1.7 & 1.7 & 1.8 & 1.8 & 2.5 & 2.6 & 2.6 & 3.1 \\
\hline & 17.6 & 17.2 & 18.9 & 17.7 & 21.6 & 19.8 & 24.3 & 22.7 \\
\hline $\mathrm{SO}_{4}^{-2}$ & 3.3 & 3.8 & 4.4 & 5.4 & 4.5 & 4.3 & 6.3 & 5.3 \\
\hline SAR & 6.7 & 6.1 & 6.4 & 5.6 & 6.9 & 6.0 & 7.7 & 6.3 \\
\hline class of water & C3-S2 & C3-S2 & C4-S2 & $\mathrm{C} 4-\mathrm{S} 2$ & C4-S2 & C4-S2 & C4-S2 & C4-S2 \\
\hline \multirow{2}{*}{\multicolumn{9}{|c|}{$\begin{array}{l}\text { Available of } \\
\text { micronutrients (ppm) } \\
\mathrm{Fe}\end{array}$}} \\
\hline & 1.5 & 1.1 & 1.4 & 1.2 & 1.7 & 1.6 & 1.7 & 1.9 \\
\hline $\mathrm{Zn}$ & 1.5 & 1.4 & 1.3 & 1.2 & 1.7 & 1.4 & 1.4 & 1.4 \\
\hline $\mathrm{Cu}$ & 0.2 & 0.2 & 0.2 & 0.1 & 0.2 & 0.1 & 0.2 & 0.1 \\
\hline $\mathrm{Mn}$ & 0.1 & 0.2 & 0.1 & 0.1 & 0.2 & 0.1 & 0.2 & 0.2 \\
\hline
\end{tabular}

The reason for using magnetic devices is not for the chemical change of the salts in MTW (only about 10\% decrease) but due to the magnetic water's ability to affect directly at the chemical and physical properties of the soil, then its indirect effect on the plant uptake of available nutrients (Selim , 2008; Maheshwari \& Grewal , 2009 and Abou ElYazied et al., 2012). The main properties of
MTW are reduction of water molecules, stores within the water. When that water passing through the soil leads to positive charges in the chemical and physical properties, i.e. reduce soil EC and $\mathrm{pH}$; improve the soil permeability, fastness water movement to dissolve soil salts, entail a better assimilation of nutrients which become available to plant uptake (Grewal and Maheshwari, 2011). 
TABLE 6. Effect of magnetic treatment on the hypothetical composition of the irrigation ground water

\begin{tabular}{|c|c|c|c|c|c|c|c|c|}
\hline Location & $\begin{array}{l}\text { Magnetic } \\
\text { treatment }\end{array}$ & $\begin{array}{l}\text { TDS } \\
(\mathrm{ppm})\end{array}$ & $\begin{array}{c}\mathrm{Ca}\left(\mathrm{HCO}_{3}\right)_{2} \\
\%\end{array}$ & $\begin{array}{c}\mathrm{CaSO}_{4} \\
\%\end{array}$ & $\underset{\%}{\mathrm{CaCl}_{2}}$ & $\underset{\%}{\mathrm{MgCl}_{2}}$ & $\begin{array}{c}\mathrm{NaCl} \\
\%\end{array}$ & $\begin{array}{c}\mathrm{KCI} \\
\%\end{array}$ \\
\hline \multirow{2}{*}{ Well (1) } & $\begin{array}{c}\text { Without } \\
\text { (Nov.2013) }\end{array}$ & 1388 & 7.47 & 14.90 & 7.13 & 6.60 & 60.33 & 1.75 \\
\hline & $\begin{array}{c}\text { With } \\
\text { (Jan.2014) }\end{array}$ & 1369 & 7.49 & 16.74 & 11.01 & 5.73 & 58.15 & 0.88 \\
\hline \multirow[t]{2}{*}{ Well (2) } & $\begin{array}{c}\text { Without } \\
\text { (Nov.2013) }\end{array}$ & 1632 & 8.11 & 17.53 & 8.37 & 7.96 & 57.37 & 1.6 \\
\hline & $\begin{array}{c}\text { With } \\
\text { (Jan.2014) }\end{array}$ & 1593 & 7.23 & 21.69 & 10.56 & 5.60 & 53.21 & 1.61 \\
\hline \multirow[t]{2}{*}{ Well (3) } & $\begin{array}{c}\text { Without } \\
\text { (Nov.2013) }\end{array}$ & 1798 & 8.74 & 15.73 & 6.30 & 9.44 & 58.04 & 1.75 \\
\hline & $\begin{array}{c}\text { With } \\
\text { (Jan.2014) }\end{array}$ & 1702 & 9.74 & 16.1 & 11.96 & 6.0 & 54.0 & 1.5 \\
\hline \multirow[t]{2}{*}{ Well (4) } & $\begin{array}{c}\text { Without } \\
\text { (Nov.2013) }\end{array}$ & 2118 & 7.8 & 19.0 & 3.00 & 9.4 & 59.3 & 2.18 \\
\hline & $\begin{array}{c}\text { With } \\
\text { (Jan.2014) }\end{array}$ & 1996 & 9.96 & 17.04 & 10.61 & 7.08 & 53.7 & 1.61 \\
\hline \multirow[t]{2}{*}{$\begin{array}{l}\text { Mean } \\
\text { values: }\end{array}$} & $\begin{array}{c}\text { Without } \\
\text { (Nov.2013) }\end{array}$ & 1734 & 8.03 & 16.79 & 6.20 & 8.36 & 58.80 & 1.82 \\
\hline & $\begin{array}{c}\text { With } \\
\text { (Jan.2014) }\end{array}$ & 1665 & 8.74 & 18.63 & 10.27 & 6.09 & 54.75 & 1.52 \\
\hline
\end{tabular}

\section{Effect of MTW on soil chemical properties}

Results of the field experiment due to the effects of MTW on soil properties are recorded in Tables 7(a,b), 8 \& 9 and reveal the following:

\section{a-The dissolving of soil salts}

There is decrease in EC in soil paste extract where the values decreased from 4.38 , 4.88, 5.68 and $6.15 \mathrm{dSm}-1$ before using MTW (i.e. High saline soils)to 2.73,3.28,3.7 and $4.15 \mathrm{dSm}-1$ (i.e. moderate saline soils) after one month of using MTW, then become 1.45, $1.90,2.48$ and $2.83 \mathrm{dSm}-1$ (i.e. low saline soils) after eight months of using MTW. for the cultivation sectors of apricot, peach, Flame seedless grape and Thompson seedless grape, respectively. These results revel that the irrigation with MTW can be considered as one of the most valuable modern technologies that can assist in reducing salt accumulation in soils and improve soil conditions around plant roots. Amiri and Dadkhah(2006); Babu(2010) and Al Khazan et al.(2011) cleared that the dissolving properties of water increase when started with magnetic field as the magnetic water has small molecules, less viscosity, faster water movement and permeability at soil pores. Hilal et al. (2012) mentioned that total salts removal from soil with MTW was greater by $24.39 \%$ compared with normal water.MTW removes the excess of soluble salts and leaches the salts for away than root zone (Hilal et al., 2012 and Abou El Yazied et al., 2012).

\section{b. Soil pH}

The results clarified that the soil $\mathrm{pH}$ is decreased from 8.3-8.2 before using MTW to 8. 2 -8.0 after one month and to 8.03 -7.9 fter eight months from using MTW. Maheshwari and Grewal 2009, Al Khazan et al. 2011 and Abou El Yazied et al. 2012 deduced that reduction in soil $\mathrm{pH}$ is due to the effect of magnetic field on organic matter in the soil where it releases relatively greater of organic acids in rhizosphere.

c. Soluble Content of $\mathrm{Ca}, \mathrm{Mg}, \mathrm{K}, \& \mathrm{Na}$ in Soil In respect of the essential elements for plants, i.e. $\mathrm{Ca}, \mathrm{Mg}, \mathrm{K}$ and $\mathrm{Na}$, the results revealed that MTW affected the solubility of these elements in the soil. The mean value of soluble contents of these elements are changed from 21.3, 8.8, 1.3 and $21.5 \%$ before using magnetic treatment of water to $10.4,4.7,0.7$ and $6.0 \%$ after eight months of using MTW for $\mathrm{Ca}, \mathrm{Mg}, \mathrm{K}$ and $\mathrm{Na}$ respectively(Table $7 \mathrm{~b}$ ). This is clear that the solubility of these elements is decreased by 51.2 , $46.6,46.2$ and $72.2 \%$ respectively. It appears that MTW leads to intensive reduction of soluble $\mathrm{Na}$ salts $(>70 \%$, meanwhile the decrease of other elements $(\mathrm{Ca}, \mathrm{Mg}$ and $\mathrm{K}$ ) is less than $50 \%$. Nave, 2008 said that MTW lead to an increase in all elements content except sodium. This is because $\mathrm{Na}$ is paramagnetic elements which have a small positive susceptibility to magnetic fields, while other elements are diamagnetic which are slightly repelled by a magnetic field. Maheshwari and Grewal (2009) and Hilal et al.( 2012) recorded an increase of $\mathrm{Ca}, \mathrm{Mg}, \mathrm{K}$ concentration into plants. 
TABLE (7a). Effect of magnetic treatment of the irrigation water on soil chemical properties

\begin{tabular}{|c|c|c|c|c|c|c|c|c|c|c|c|c|}
\hline \multirow[t]{4}{*}{ Properties } & \multicolumn{12}{|c|}{ location } \\
\hline & \multicolumn{3}{|c|}{$\begin{array}{c}\text { Apricot } \\
\text { region }\end{array}$} & \multicolumn{3}{|c|}{$\begin{array}{l}\text { Peach } \\
\text { region }\end{array}$} & \multicolumn{3}{|c|}{$\begin{array}{l}\text { Flame seedless- } \\
\text { grape region }\end{array}$} & \multicolumn{3}{|c|}{$\begin{array}{l}\text { Thompson seedless- } \\
\text { grape region }\end{array}$} \\
\hline & \multicolumn{12}{|c|}{ Schedule of magnetic treatment } \\
\hline & $1 \mathrm{~B}$ & $\mathbf{1 A}$ & $\mathbf{8 A}$ & $1 \mathrm{~B}$ & $\mathbf{1 A}$ & 8A & $1 \mathrm{~B}$ & $1 \mathrm{~A}$ & 8A & $1 \mathrm{~B}$ & $\mathbf{1 A}$ & 8A \\
\hline \multirow{3}{*}{$\begin{array}{c}\text { SP } \\
\text { EC }\left(\mathbf{d s m}^{-1}\right) \\
\text { pH }\end{array}$} & 19.5 & 20 & 19.5 & 20 & 21 & 22.5 & 22 & 22.5 & 23 & 22.5 & 20.8 & 21.9 \\
\hline & 4.38 & 2.73 & 1.45 & 4.88 & 3.28 & 1.9 & 5.68 & 3.70 & 2.48 & 6.15 & 4.15 & 2.83 \\
\hline & 8.3 & 8.2 & 8.05 & 8.3 & 8.2 & 8.0 & 8.2 & 8.03 & 7.9 & 8.2 & 8.1 & 7.9 \\
\hline \multirow{2}{*}{\multicolumn{13}{|c|}{$\begin{array}{l}\text { Soluble cations } \\
\text { meq/l } \mathrm{Ca}^{+2}\end{array}$}} \\
\hline & 22.0 & 14.2 & 7.3 & 19.1 & 15.7 & 9.3 & 21.8 & 18.1 & 11.5 & 22.3 & 19.4 & 13.6 \\
\hline $\mathbf{M g}^{+2}$ & 5.8 & 3.8 & 3.1 & 8.8 & 4.9 & 3.3 & 9.9 & 5.3 & 6.1 & 10.8 & 6.4 & 6.2 \\
\hline $\mathbf{N a}^{+}$ & 15.1 & 8.1 & 3.4 & 19.2 & 10.7 & 5.5 & 23.5 & 12.4 & 6.5 & 28.1 & 14.4 & 8.2 \\
\hline $\mathbf{K}^{+}$ & 1.0 & 1.1 & 0.6 & 1.4 & 0.8 & 0.6 & 1.6 & 1.1 & 0.7 & 1.3 & 1.2 & 0.7 \\
\hline \multirow{5}{*}{$\begin{array}{c}\text { Soluble anions } \\
\text { meq// } \mathrm{CO}_{3}^{-2} \\
\mathrm{HCO}_{3}^{-} \\
\mathrm{Cl}^{-} \\
\mathrm{SO}_{4}^{-2}\end{array}$} & & & & & & & & & & & & \\
\hline & --- & --- & --- & --- & --- & --- & --- & --- & --- & --- & --- & --- \\
\hline & 2.1 & 1.8 & 1.9 & 2.9 & 1.9 & 2.6 & 3.1 & 2.9 & 2.3 & 3.3 & 3.1 & 2.6 \\
\hline & 26.6 & 14.4 & 5.8 & 26.9 & 15.9 & 7.6 & 33.0 & 17.3 & 12.2 & 36.5 & 19.3 & 14.4 \\
\hline & 15.2 & 11 & 6.7 & 18.7 & 14.4 & 8.5 & 20.7 & 16.7 & 10.6 & 22.7 & 19 & 11.7 \\
\hline
\end{tabular}

TABLE (7b). the mean values of essential elements (Soluble cations meq/l )

\begin{tabular}{|l|c|c|c|c|}
\hline & $\mathbf{C a}^{+2}$ & $\mathbf{M g}^{+2}$ & $\mathbf{N a}^{+}$ & $\mathbf{K}^{+}$ \\
\hline 1month before treated & 21.3 & 8.8 & 21.5 & 1.3 \\
\hline 8months after treated & 10.4 & 4.7 & 6.0 & 0.7 \\
\hline
\end{tabular}

Data in Table 8 show that $\mathrm{Ca}(\mathrm{HCO} 3) 2$ is decreased from $2.8 \%$ to $2.4 \%$ before and after using MTW. Samir (2008) cleared that in unmagnetic water, some of carbonates are deposited in soil pores and on the plant roots, but using MTW, and carbonate salts cannot precipitate. As well as, MTW can break the precipitated salts on internal surface of irrigation pipes and laterals, thus the movement of water than untreated.

\section{d. Available Nutrients in Soil}

The results in Table 9 revealed the effect of MTW on the micro and macro-nutrients during the fertilization period (from march to July 2014). The mean values of micronutrients are ranged from 3.9, 4.9, 1.0 and $8.0 \mathrm{ppm}$ (at March ) to 5.1, 9.5,3.7 and $11.5 \mathrm{ppm}$ (in July) for $\mathrm{Fe}, \mathrm{Zn}, \mathrm{Cu}$ and $\mathrm{Mn}$ respectively. Whereas, the mean values of macro-nutrients varied between 62.3. 68.5 and $362.5 \mathrm{ppm}$ (at march) to $32.3,43.3$ and $246.8 \mathrm{ppm}$ (in July) for N,P and K respectively. Noran et al. 1996 and Maheshwari and Grewal,2009 mentioned that plants absorb more water of MTW than non-treated, consequently they uptake more nutrients as a result of water molecules of MTW are minute and small and is reflected on

TABLE 8. Effect of magnetic treatment of irrigation water on the hypothetical composition of soil paste extract (meq/l)

\begin{tabular}{|c|c|c|c|c|c|c|}
\hline $\begin{array}{c}\text { Schedule magnetic treatment } \\
\text { 1 month before treated } \\
\text { (Nov.2013) }\end{array}$ & $\mathbf{C a}\left(\mathbf{H C O}_{3}\right)_{2}$ & $\mathbf{C a S O}_{\mathbf{4}}$ & $\mathbf{C a C l}_{\mathbf{2}}$ & $\mathbf{M g C l}_{\mathbf{2}}$ & $\mathbf{N a C l}$ & $\mathbf{K C l}$ \\
\hline $\begin{array}{c}\text { month after treated } \\
\text { (Jan.2014) }\end{array}$ & 2.8 & 18.5 & 0.8 & 8.0 & 21.5 & 1.4 \\
\hline $\begin{array}{c}\text { 8 months after treated } \\
\text { (Agu.2014) }\end{array}$ & 2.4 & 8.0 & 1.4 & 3.0 & 6.3 & 0.7 \\
\hline
\end{tabular}

Egypt. J. Soil Sci. 57 No. 1 (2017) 
the yield and water productivity. These results clear that MTW have played important role in improving the availability of these elements to plants. Selim (2008) indicated that MTW has induced changes in the mobility of nutrient elements in root zone which there is difference from one element to another according to element magnetic susceptibility.

\section{Effect of MTW on crop production}

The crop production of apricot, peach, Flame seedless grape and Thompson seedless grape
(Table 10 and Fig. 2) with MTW is increased as compared to those irrigated without treatment. The increase in crop production using MTW for the above trees is $40,29,28$ and $19 \%$ over untreated, respectively.

The difference in the crop production between the different trees lead to different toleration of these trees to water and soil salinity according to Hofman (1977). Hilal and Hillal (2000 a\&b) showed that there is indirect effects of MTW on plant growth through its positive effect on the soil

TABLE 9. Effect of magnetic treatment of irrigation water on mean values of available micro and macronutrients (ppm)

\begin{tabular}{|c|c|c|c|c|c|c|c|c|}
\hline \multirow{2}{*}{ Location } & \multirow{2}{*}{$\begin{array}{c}\text { Schedule of magnetic } \\
\text { treatment }\end{array}$} & \multicolumn{4}{|c|}{ Available micronutrients in soil } & \multicolumn{3}{|c|}{ Available macronutrients } \\
\hline & & $\mathbf{F e}$ & $\mathbf{Z n}$ & $\mathbf{C u}$ & Mn & $\mathbf{N}$ & $\mathbf{P}$ & $\mathbf{K}$ \\
\hline \multirow[t]{2}{*}{$\begin{array}{l}\text { Apricot } \\
\text { region }\end{array}$} & $\begin{array}{c}3 \text { month after treated } \\
(\text { marsh2014) }\end{array}$ & 2.7 & 3.5 & 0.6 & 5.3 & 60 & 72 & 308 \\
\hline & $\begin{array}{l}\text { 6month after treated } \\
\text { (july2014) }\end{array}$ & 5.7 & 11.6 & 3.7 & 14.9 & 32 & 33 & 206 \\
\hline \multirow[t]{2}{*}{$\begin{array}{l}\text { Peach } \\
\text { region }\end{array}$} & $\begin{array}{c}3 \text { month after treated } \\
(\text { march2014) }\end{array}$ & 3.2 & 4.5 & 0.8 & 7.1 & 55 & 65 & 356 \\
\hline & $\begin{array}{l}\text { 6month after treated } \\
\text { (july2014) }\end{array}$ & 4.9 & 11.9 & 5.6 & 13.4 & 58 & 66 & 290 \\
\hline \multirow{2}{*}{$\begin{array}{l}\text { Flame- } \\
\text { grape } \\
\text { region }\end{array}$} & $\begin{array}{l}3 \text { month after treated } \\
(\text { marsh2014) }\end{array}$ & 4.3 & 5.4 & 1.3 & 9.1 & 69 & 67 & 384 \\
\hline & $\begin{array}{c}\text { 6month after treated } \\
\text { (july2014) }\end{array}$ & 4.9 & 6.9 & 3.2 & 8.3 & 38 & 38 & 226 \\
\hline \multirow{2}{*}{$\begin{array}{l}\text { Seedless- } \\
\text { grape } \\
\text { region }\end{array}$} & $\begin{array}{l}3 \text { month after treated } \\
(\text { marsh2014) }\end{array}$ & 5.3 & 6.3 & 1.4 & 10.4 & 65 & 70 & 402 \\
\hline & $\begin{array}{l}\text { 6month after treated } \\
\text { (july2014) }\end{array}$ & 4.7 & 7.7 & 2.4 & 9.3 & 31 & 36 & 265 \\
\hline \multirow[t]{2}{*}{$\begin{array}{l}\text { Mean } \\
\text { values }\end{array}$} & $\begin{array}{c}3 \text { month after treated } \\
(\text { marsh2014) }\end{array}$ & 3.9 & 4.9 & 1.0 & 8.0 & 62.3 & 68.5 & 362.5 \\
\hline & 6month after treated & 5.1 & 9.5 & 3.7 & 11.5 & 32.3 & 43.3 & 246.8 \\
\hline
\end{tabular}

TABLE 10 . Effect of MTW on crop production

\begin{tabular}{|c|c|c|c|c|c|c|c|}
\hline \multirow[b]{3}{*}{ Location } & \multirow{3}{*}{$\begin{array}{c}\text { No.of } \\
\text { trees/ } \\
\text { fed. }\end{array}$} & \multicolumn{6}{|c|}{ Mean of fruits yield } \\
\hline & & \multirow{2}{*}{$\begin{array}{c}\begin{array}{c}\text { Yield before } \\
\text { accumulati-on } \\
\text { salts in soil }\end{array} \\
\mathrm{Kg} / \\
\text { tree }\end{array}$} & \multicolumn{2}{|c|}{$\begin{array}{c}\text { Yield under } \\
\text { accumulation } \\
\text { Of salts in soil (2013) }\end{array}$} & \multicolumn{3}{|c|}{$\begin{array}{c}\text { Yield After using MTW } \\
\text { (2014) }\end{array}$} \\
\hline & & & $\begin{array}{l}\mathrm{Kg} / \\
\text { tree } \\
\end{array}$ & $\begin{array}{c}\text { Deficie- } \\
\text { ncy rate } \\
\% \\
\end{array}$ & $\begin{array}{l}\mathrm{Kg} / \\
\text { tree }\end{array}$ & $\begin{array}{c}\text { Deficie-ncy } \\
\text { rate } \%\end{array}$ & \begin{tabular}{c}
\multicolumn{2}{c}{ Increase } \\
rate $\%$
\end{tabular} \\
\hline Apricot & 168 & 60 & 20.4 & 66 & 44.4 & 26 & 40 \\
\hline Peach & 210 & 50 & 21.0 & 58 & 35.5 & 29 & 29 \\
\hline Flame seedless-grape & 800 & 40 & 19.2 & 52 & 30.4 & 24 & 28 \\
\hline Thompson seedless- grape & 800 & 20 & 6.4 & 68 & 10.2 & 48 & 19 \\
\hline
\end{tabular}

Egypt. J. Soil Sci. 57 No.1 (2017) 


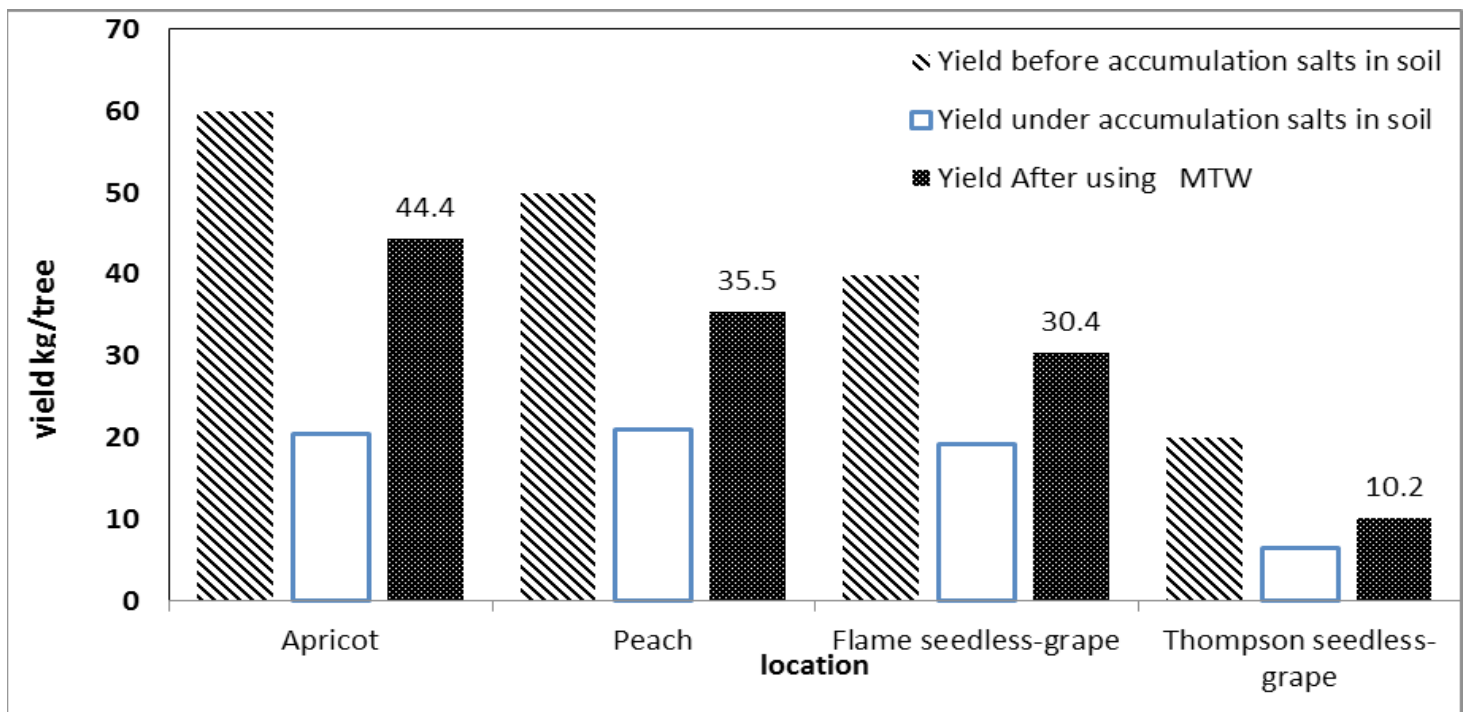

Fig. 2. Effect of MTW on crop production

TABLE 11 . Effect of MTW on water production

\begin{tabular}{|c|c|c|c|c|c|c|c|}
\hline \multirow{3}{*}{ Location } & \multirow{3}{*}{$\begin{array}{c}\text { Water } \\
\text { use/year } \\
\mathbf{m}^{3} / \text { tree }\end{array}$} & \multicolumn{6}{|c|}{ Water productivity } \\
\hline & & \multirow{2}{*}{$\begin{array}{c}\begin{array}{c}\text { before } \\
\text { accumulation } \\
\text { salts in soil }\end{array} \\
\mathrm{kg} / \mathrm{m} 3\end{array}$} & \multicolumn{2}{|c|}{$\begin{array}{l}\text { under accumulation } \\
\text { salts in soil }\end{array}$} & \multicolumn{3}{|c|}{$\begin{array}{c}\text { After using } \\
\text { MTW }\end{array}$} \\
\hline & & & $\mathrm{kg} / \mathrm{m} 3$ & $\begin{array}{c}\text { Deficiency } \\
\text { rate } \%\end{array}$ & $\mathrm{~kg} / \mathrm{m} 3$ & $\begin{array}{c}\text { Deficiency } \\
\text { rate\% }\end{array}$ & $\begin{array}{c}\text { Increasing } \\
\%\end{array}$ \\
\hline Apricot & 20.95 & 2.86 & 0.97 & 33.9 & 2.12 & 74.1 & 40.2 \\
\hline Peach & 16.78 & 2.98 & 1.25 & 41.9 & 2.12 & 71.1 & 29.2 \\
\hline Flame seedless & 4.41 & 9.07 & 4.35 & 48.0 & 6.89 & 76.0 & 28.0 \\
\hline Thompson seedles & 4.41 & 4.54 & 1.45 & 31.9 & 2.31 & 51.2 & 19.3 \\
\hline
\end{tabular}

micro flora and fauna population. Also, Esitken and Turan (2004) cleared that the increasing of the available nutrients and the decreasing of soil $\mathrm{pH}$ and soluble salts at soil solution due to using MTW lead to improve nutrient uptake and root growth.

\section{Effect of MTW on water production}

As water productivity is based on the amount of yield and water required to produce the yield. Therefore, the efficiency of water productivity, for apricot, peach, Flame seedless grape and Thompson seedless grape (Table 11) increased from 33.9, 41.9, 48.0 and $31.9 \%$ before magnetic treatment to $40.2,29.1,28.0$ and $19.3 \%$, respectively. Yinan et al. (2005) and Charan (2009) reported that a plant's metabolism contains of $90-95 \%$ water, therefore MTW increase water uptake and entail plant metabolism.

\section{Conclusion}

It is clear that the irrigation with MTW can be considered as a one of the most valuable modern technologies that can improve crop production and alleviate salinity of water and soil, as well as can assist in saving irrigation water.

\section{References}

Abou El-Yazied, A., El-Gizawy, A. M., Khalf, S. M. and El-Satar, A. (2012) Effect of magnetic field treatments for seeds and irrigation water as well as $\mathrm{N}, \mathrm{P}$ and $\mathrm{K}$ levels on productivity of tomato plants. J. applied Sci. Res.,8(4), 2088-2099.

Al-Khazan, M., Abdullatif, B.M. and Al-Assaf , N.(2011) Effect of magnetically treated water on water status, chlorophyll pigments and some 
elements content of Jojoba at different growth. African J. of Enviro. Sci. and Tech. 5 (9),722-731.

Amiri, M.C. and Dadkhah, A.A.(2006) On reduction in the surface tension of water due to magnetic treatment. Colloids Surf. A: Physicochemical Eng. Aspects, 278, 252-255.

Arab Mining and Petroleum Ass. (1970) The scientific and applied associations of ground water in UAR. The General Society of El-Amiriia Printing Offices, Cairo.

Babu C. (2010) Use of magnetic water and polymer in agriculture. Ph.D., Agronomy D.W.S.R. Centre(http@waterforlif-net.OU/agric./producefarming).

Bashour, I. I. and Sayegh, A. H. (2007) Methods of analysis for soils of arid and semi-arid regions . Food and Organ. of U.N.Rome.

Charan, R. (2009) Effect of stimulating magnetic field on plants. Indian J. of Thear. Phys., 57,15-20.

Duarte Diaz, C. E., Riquenes, J. A., Sotolongo, B. and Perez, E. (1997) Effect of magnetic treatment of irrigation water on Tomato crop . Hortic. Abst. 69,494.

Esitken A. and Turan M. (2004) Alternating magnetic field effects on yield and plant nutrient element composition of strawberry. Acta. Agric. Acad. Sect. B. Soil Plant Sci. 5493),135-139.

Grewal, H. S. and Maheshwari, B.L. (2011) Magnetic treatment of irrigation water and snow-pea and chick-pea seeds enhances early growth and nutrient contents of seedlings. Bio-electro Magnetics, 32, 58-65.

Hilal, M. H. and Hillal, M. M. (2000a) Application of magnetic technologies in desert agriculture 1.Seed germination and seedling emergence of some crop in a saline calcareous soil. Egypt J. Sci. 40 (3) 413421.

Hilal, M. H. and Hilalal, M. M. (2000b) Application of magnetic technologies in desert agriculture II Effect of irrigation magnetic treatments of irrigation water on water and on salt distribution in olive and citrus yield and induced changes of ionic balance in soil and plant. Egypt J. Soil Sci. 40(3),423-435.

Hilal, M. H., El-Fakharaniy, Y. M., Mabrouk, S.S., Mohamed, A. I and Ebead, B. M. (2012) Effect of magnetic treated irrigation water on salt removal from a sandy soil and on the availability of certain nutrients. Int. J. of Engineering and App. Sci.
Hofman (1977) Water for Agriculture, Quality Evolution. Westcot. O.W., USA..

Hozien M. (2014)Opportunetions of magnetic technology applications in Egyptian agriculture Forum. Future of Magnetic Agric. in Egypt , National Res. Cent.

Larcher W.(1995) Physiological Plant Ecology. Third edition. Springer- Ucrlag Berlin Heidelberg, New York pp.50-75

Maheshwari, B.L. and Grewal, H. S. (2009) Magnetic treatment of irrigation water: Its effects on vegetable crop yield and water productivity. Agric. Water Manage. 96,1229-1236

Nimmi, V. and Medhu, G. (2009) Effect of pre-sowing treatment with permanent magnetic field on germination and growth of Chili. Int. Agrophysics 23,195-198.

Nave, C.L.(2008) Magnetic properties of solids, Hyper Phys., 15,11-23.

Noran R., Shani, U. and Lin, I. (1996) The effect of irrigation with magnetically treated water on the translocation of mineral in the soil. Magnetic and Electrical Separation, 7,109-122.

Samir, H. N.(2008)The effect of magnetic water on growth of chick-pea seeds. Eng. \&Tech. 26, 9

Selim, M.M. (2008) Application of magnetic technologies in correcting under ground brackish water for irrigation in the arid and semi arid ecosystem. The 3rd Inter. Conf. on water Res. And Environment and the 1st Arab Water Forum.

Stephen, L. (2013) Magnetic water treatment and pseudo Science. Htt://ww/chem/1.com/CQ/ magscan.

UNDESCO System(1954) Review of research on problems of utilization of saline water. U.N. Ed. Sci. and Cult. Organ, U.S.A

Yinan, Y., Yuan, L., Yongqinq, Y. and Chunnang, L. (2005)Effect of seed pretreatment by magnetic field on sensitivity of cucumber seedlings to ultraviolet-B radiation. Environment and Experimental Botany 54, 286-294.

( Received: 10/8/2016; accepted:27/11/2016)

Egypt. J. Soil Sci. 57 No.1 (2017) 


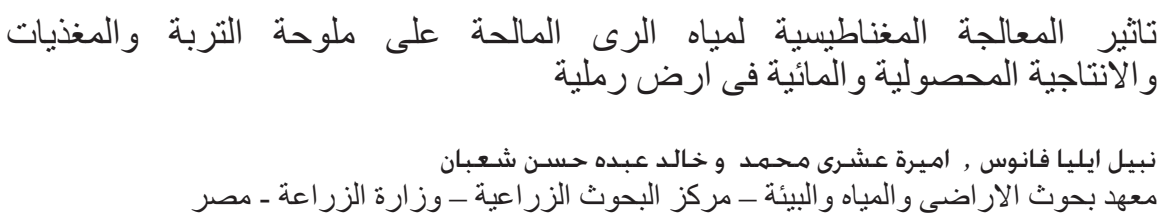

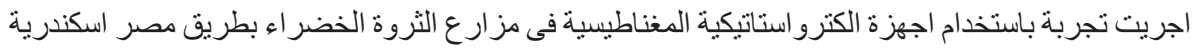

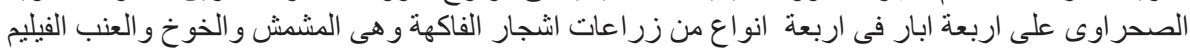

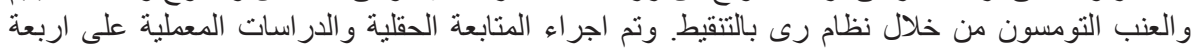

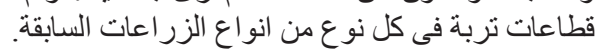

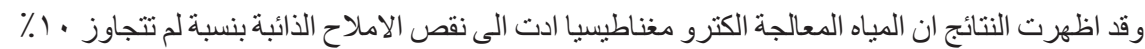

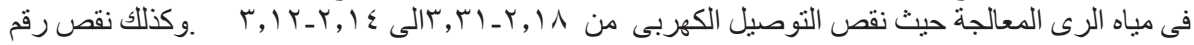

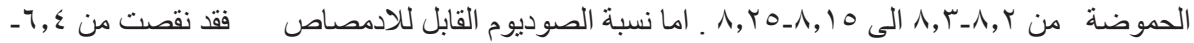

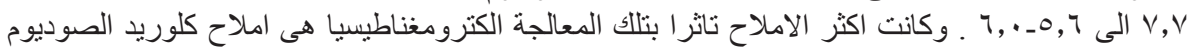

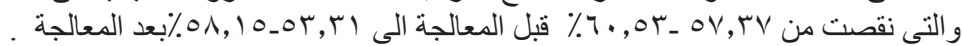

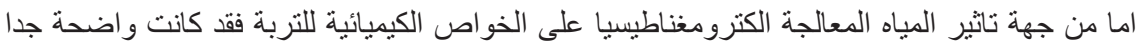

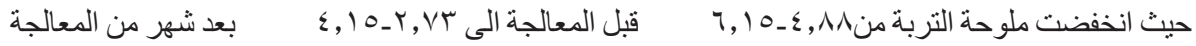

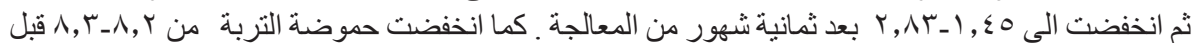

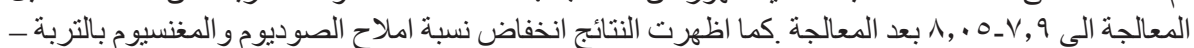

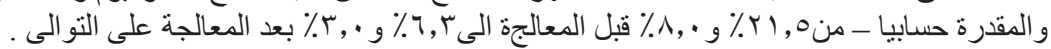

وايضا ظهر ناثيرالمعالجة الالكترو مغناطيسية لماء الرى على زيادة تيسر العناصر الغذائية/لكبرى

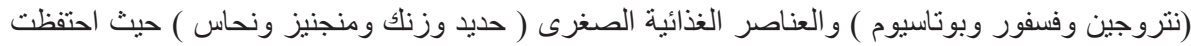

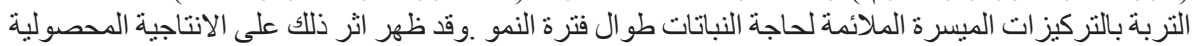

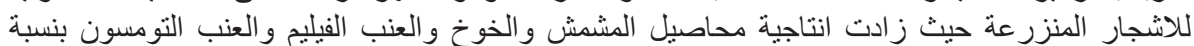

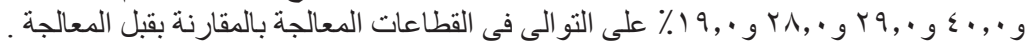

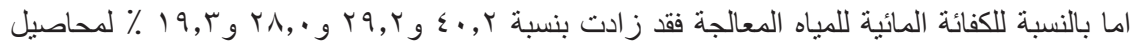

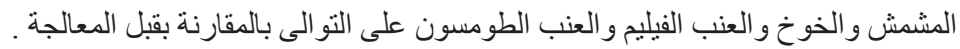

النتائج السابقة تظهر اهمية استخدام تكنولوجيا المعالجة الالكترومغناطيسة فى الاراضى والمياه المالحة

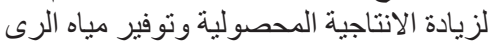

